\title{
Pathophysiology of carotid-cavernous fistulas in vascular Ehlers-Danlos syndrome: a retrospective cohort and comprehensive review
}

Salma Adham 1,2, Denis Trystram³,4, Juliette Albuisson 1,2,5, Valérie Domigo 3,4, Anne Legrand 1,2,5, Xavier Jeunemaitre ${ }^{1,2,5}$ and Michael Frank $k^{1,5^{*}}$

\begin{abstract}
Background: Vascular Ehlers-Danlos syndrome (VEDS) is a rare condition characterized by connective tissue fragility. Direct spontaneous carotid-cavernous fistula (SCCF) is reportedly pathognomonic of vEDS. We conducted this study to understand the possible mechanisms of occurrence of sCCF in this subset of patients.

Methods: We conducted a retrospective analysis of a monocentric VEDS cohort along with a literature review regarding SCCF in this condition.

Results: Of 133 patients regularly followed in our centre between 2000 and 2017, 13 (9.8\%) had a diagnosis of direct SCCF (92.3\% female, median age 33.0 years, interquartile range (IQR) [26.0-39.5]). There were 7 Glycine missense and 6 splice-site variants but no variant leading to haploinsufficiency. The literature search identified 97 vEDS patients with direct SCCF (79.4\% female, 7.2\% sex not reported, median age 31.0 years, IQR [24.0-39.0]). Increased carotid circumferential wall stress, higher carotid distensibility and lower carotid intima-media thickness could contribute to a higher risk for direct SCCF in VEDS. There is no predictive factor for the occurrence of sCCF apart from female sex in vEDS.

Conclusions: In vEDS, anatomical and pathophysiological features of the intra-cavernous internal carotid artery make it prone to shunting in the cavernous sinus, due either to a spontaneous rupture or to a spontaneous dissection with pseudoaneurysm formation. Direct sCCF in seemingly healthy young individuals should be highly suggestive of $V E D S$ and prompt further investigation.
\end{abstract}

Keywords: Vascular Ehlers-Danlos syndrome, Rare vascular disease, Genetics, Carotid-cavernous fistula, Neurology, Neuroophthalmology, Pathophysiology

\section{Background}

Vascular Ehlers-Danlos syndrome (vEDS, OMIM \#130050) is a rare inherited connective tissue disorder with a prevalence estimated at $1 / 150000$. It is an autosomal dominant transmitted disorder caused by diverse mutations in the COL3A1 gene which encodes the pro-alpha1 chain of type

\footnotetext{
* Correspondence: michael.frank@aphp.fr

${ }^{1}$ Hôpital Européen Georges Pompidou, Département de Génétique, Centre de Référence des Maladies Vasculaires Rares, Hôpital Européen Georges Pompidou, AP-HP, 20-40 rue Leblanc, 75908 Paris Cedex 15, France ${ }^{5}$ INSERM, U970, Paris centre de Recherche Cardiovasculaire - PARCC, Paris, France

Full list of author information is available at the end of the article
}

III procollagen [1-3]. Vascular EDS is characterized by connective tissue fragility leading to life-threatening complications in seemingly healthy young adults. Easy bruising, thin and translucent skin, acrogeria and characteristic facial features may be a hint for clinicians. Intestinal and uterine fragility are classical features of vEDS, but generalized arterial fragility dominates the clinical picture with spontaneous dissections, aneurysms and arterial ruptures [2].

It is therefore unsurprising that vEDS has been associated with the development of spontaneous direct carotid-cavernous fistula (sCCF). Carotid-cavernous fistula $(\mathrm{CCF})$ is an abnormal communication between the

(c) The Author(s). 2018 Open Access This article is distributed under the terms of the Creative Commons Attribution 4.0 International License (http://creativecommons.org/licenses/by/4.0/), which permits unrestricted use, distribution, and 
high-pressure carotid arterial system and the low-pressure cavernous venous system (CS). In direct CCF, internal carotid artery (ICA) wall disruption allows high-pressure blood to move into the CS, resulting in short-circuiting of the ICA arterial blood into the venous system of the CS. The most common symptoms are swelling of the eye, chemosis, pain, ophthalmoplegia and bruit [4]. Direct sCCF is rare in the general population as most direct fistulas are posttraumatic but seems to be more common in vEDS patients and especially in females.

We report in this article a series of 13 molecularly proven vEDS patients diagnosed with direct sCCF along with a review on literature regarding direct $\mathrm{sCCF}$ occurring in vEDS patients. The possible mechanisms of occurrence in this subset of patients are discussed.

\section{Methods}

\section{Study population}

Since 2000, all molecularly proven vEDS patients followed in our department are systematically monitored clinically, biologically and by means of imaging (Doppler ultrasound, MR-Angiogram and/or CT-scan) at regular time intervals.

Patients with vEDS regularly followed in the French National Reference Centre for rare vascular diseases between 2000 and 2017 were included in this retrospective cohort study. Probands and relatives were diagnosed with vEDS based on clinical presentation, physical examinations, radiological findings and confirmation of a pathogenic variant in the COL3A1 gene. Genetic testing was performed in compliance with the French legislation on genetic diagnostic tests (French bioethics law no. 2004-800) and written informed consent was given by all patients. A retrospective review of medical records for this study was approved by an ethical standards committee, the Comite de Protection des Personnes Ile-de-France 2 (IRB 00001072). Medical history was reviewed to identify patients suffering from direct sCCF. Patients' characteristics were reported only for the patients with fistulas.

\section{Statistical analysis}

A statistical analysis was performed with the XLStat software (Addinsoft, version 2017.4). To analyse patients' characteristics, time-independent qualitative variables were compared using Chi-square test or Fisher's exact test whenever the count was insufficient. Quantitative variables were reported using parametric descriptive statistics. A $P$ value $<0.05$ was considered significant.

\section{Literature review}

A literature search was performed via computer literature searches. Articles were identified through a systematic PubMed search and by a review of their respective references. Available articles in English or in French regarding direct sCCF in vEDS patients were included.

\section{Results \\ Study population}

Since 2000, our centre has followed 148 molecularly proven vEDS patients. We identified 15 individuals either with variants leading to haploinsufficiency $(n=12)$ or with non-Glycine missense variants within the triple helix and non-Glycine missense variants or in-frame insertions-deletions in the $\mathrm{N}$ - or C-terminal part of the protein $(n=3)$. None of these 15 patients had a history of direct sCCF. Of 133 patients known to have either Glycine missense or splice-site and in-frame insertions-deletions variants in the COL3A1 gene, there were 79 (59.4\%) females, 90 (67.7\%) Glycine missense variants, 55 (41.4\%) patients with a history of digestive event and 66 (49.6\%) patients with a history of acute arterial event.

Among these 133 patients, we identified 13 (9.8\%) individuals who suffered from direct sCCF diagnosed between January 1985 and September 2014 (Table 1). There were 7 (53.8\%) Glycine missense variants and 6 (46.2\%) splice-site variants (OR 0.52 with a $95 \%$ confidence interval $(\mathrm{CI})[0.14$, 2.02], $P$ 0.349). There were 12 (92.3\%) females and 1 (7.7\%) male (OR 0.11 with a $95 \%$ confidence interval (CI) [0.002$0.760], P 0.014)$. The median age at molecular diagnosis was 32.0 years, interquartile range (IQR) [28.0-39.0]. The median age at time of direct sCCF diagnosis was 33.0 years, IQR [26.0-39.5].

Direct sCCF was the first symptomatic vascular complication reported in $9(69,2 \%)$ patients (cases 1 to 5,7 to 9 and 11). Of 13 patients, 5 (38.5\%) had already been diagnosed with vEDS 44.0 months, IQR [7.0-60.5], before the occurrence of the fistula (cases 5, 6, 8, 12 and 13). Occurrence of a direct sCCF led to vEDS molecular diagnosis in less than 15 months in 4 (30.8\%) patients (cases 4, 7, 9 and 11, median diagnosis time 7.5 months, IQR [6.0-9.0]). Molecular diagnosis of vEDS was delayed to 79.5 months, IQR [49.5-166.5], after the sCCF in the 4 (30.8\%) remaining patients (cases 1 to 3, case 10).

Data regarding the previous ICA status was not available in $4(30.8 \%)$ patients (cases $2,4,8$ and 10). No previously known aneurysm or dissection of the ICA was found in the medical history or in the radiological reports of $3(23.0 \%)$ patients (cases 3, 9 and 13). Imaging during the systematic follow-up described a dysplastic aspect of the petrous ICA (probably secondary to a dissection) a few months before the ipsilateral sCCF diagnosis in one patient (case 6). Imaging at the time of the sCCF described an aspect of ICA dissection ipsilateral to the fistula in 4 (30.8\%) patients (cases 1, 5, 7 and 12). Another patient (case 11) was diagnosed with cavernous ICA dissection and petrous aneurysm rupture leading to an ipsilateral fistula a few weeks later. Overall, there was 
Table 1 Case series

\begin{tabular}{|c|c|c|c|c|c|c|c|c|c|}
\hline $\begin{array}{l}\text { Case } \\
\text { no. }\end{array}$ & Age (years) & Sex & sCFF side & Treatment & Outcome & IMT (mm) & $\begin{array}{l}\text { COL3A1 variant } \\
\text { CDNA }\end{array}$ & Protein & Type \\
\hline 1 & 34 & $F$ & Left & ICA sacrifice & Alive & 0.383 & c. $665 \mathrm{G}>\mathrm{A}$ & p.(Gly222Asp) & Glycine \\
\hline 2 & 30 & $\mathrm{~F}$ & Right & $\begin{array}{l}\text { CCF closure } \\
\text { (embolization) }\end{array}$ & Alive & 0.354 & $c .2735 G>A$ & p.(Gly912Asp) & Glycine \\
\hline 3 & 13 & $\mathrm{~F}$ & Left & $\begin{array}{l}\text { CCF closure } \\
\text { (embolization) }\end{array}$ & Alive & 0.339 & $c .951+1 G>A$ & p.? & Splice \\
\hline 4 & 21 & $\mathrm{~F}$ & Left & $\begin{array}{l}\text { CCF closure } \\
\text { (embolization) }\end{array}$ & Alive & 0.372 & c. $2553+1 \mathrm{G}>\mathrm{A}$ & p.? & Splice \\
\hline 5 & 33 & $\mathrm{~F}$ & Right & $\begin{array}{l}\text { CCF closure } \\
\text { (embolization) }\end{array}$ & Alive & 0.394 & C. $1662+1 G>A$ & p.? & Splice \\
\hline 6 & 42 & $\mathrm{~F}$ & Left & ICA sacrifice & Alive & 0.387 & c.3441_3485dup & p.(Lys1150_Gly1164dup) & Duplication \\
\hline 7 & $\begin{array}{l}27 \\
31\end{array}$ & $\mathrm{~F}$ & $\begin{array}{l}\text { Right } \\
\text { Left }\end{array}$ & $\begin{array}{l}\text { CCF closure } \\
\text { (embolization) }\end{array}$ & Died aged 38 & 0.319 & c. $2222 \mathrm{G}>\mathrm{A}$ & p.(Gly741Asp) & Glycine \\
\hline 8 & 38 & $\mathrm{~F}$ & Right & $\begin{array}{l}\text { CCF closure } \\
\text { (embolization) }\end{array}$ & Alive & 0.503 & c. $2095 \mathrm{G}>\mathrm{C}$ & p.(Gly699Arg) & Glycine \\
\hline 9 & 25 & $\mathrm{~F}$ & Right & $\begin{array}{l}\text { CCF closure } \\
\text { (embolization) }\end{array}$ & Alive & NR & C.898-1G>C & p.? & Splice \\
\hline 10 & 36 & $\mathrm{~F}$ & Right & $\begin{array}{l}\text { CCF closure } \\
\text { (embolization) }\end{array}$ & Alive & 0.435 & c. $2293 \mathrm{G}>\mathrm{C}$ & p.(Gly252Arg) & Glycine \\
\hline 11 & 28 & M & Right & $\begin{array}{l}\text { CCF closure } \\
\text { (embolization) }\end{array}$ & Alive & NR & $\begin{array}{l}\text { C.[1347+ } \\
1 \mathrm{G}>\mathrm{A}] ;[=]\end{array}$ & p.? & Splice \\
\hline 12 & 49 & $\mathrm{~F}$ & Right & $\begin{array}{l}\text { CCF closure } \\
\text { (embolization) }\end{array}$ & Alive & 0.417 & c. $755 \mathrm{G}>\mathrm{T}$ & p.(Gly252Val) & Glycine \\
\hline 13 & 41 & $\mathrm{~F}$ & Left & $\begin{array}{l}\text { Died before } \\
\text { treatment }\end{array}$ & Died aged 41 & NR & c. $826 \mathrm{G}>\mathrm{A}$ & p.(Gly276Ser) & Glycine \\
\hline $\begin{array}{l}\text { Case } \\
\text { no. }\end{array}$ & \multicolumn{2}{|c|}{$\begin{array}{l}\text { Age at molecular } \\
\text { diagnosis (years) }\end{array}$} & $\begin{array}{l}\text { 1st vascular } \\
\text { event }\end{array}$ & $\begin{array}{l}\text { Age at 1st } \\
\text { vascular event } \\
\text { (years) }\end{array}$ & $\begin{array}{l}\text { Acute arterial } \\
\text { events } \\
\text { (other than sCCF) }\end{array}$ & $\begin{array}{l}\text { 1st digestive } \\
\text { event }\end{array}$ & \multicolumn{2}{|c|}{$\begin{array}{l}\text { Age at 1st digestive } \\
\text { event (years) }\end{array}$} & \\
\hline 1 & 38 & & sCCF & 34 & Yes & $\begin{array}{l}\text { Incisional } \\
\text { hernia }\end{array}$ & \multicolumn{2}{|l|}{32} & \\
\hline 2 & 35 & & sCCF & 30 & Yes & - & \multicolumn{2}{|l|}{ - } & \\
\hline 3 & 32 & & sCCF & 13 & Yes & $\begin{array}{l}\text { Postoperative } \\
\text { adhesive } \\
\text { intestinal } \\
\text { obstruction }\end{array}$ & \multicolumn{2}{|l|}{25} & \\
\hline 4 & 22 & & sCCF & 21 & No & - & \multicolumn{2}{|l|}{ - } & \\
\hline 5 & 28 & & sCCF & 33 & Yes & $\begin{array}{l}\text { Intestinal } \\
\text { perforation }\end{array}$ & \multicolumn{2}{|l|}{21} & \\
\hline 6 & 38 & & $A R$ & 33 & Yes & - & \multicolumn{2}{|l|}{ - } & \\
\hline 7 & 28 & & sCCF & 27 & Yes & Diverticulitis & \multicolumn{2}{|l|}{26} & \\
\hline 8 & 32 & & sCCF & 38 & Yes & - & \multicolumn{2}{|l|}{ - } & \\
\hline 9 & 25 & & SCCF & 25 & Yes & $\begin{array}{l}\text { Occlusion on } \\
\text { paresis }\end{array}$ & \multicolumn{2}{|l|}{25} & \\
\hline 10 & 45 & & AVF & 24 & Yes & - & \multicolumn{2}{|l|}{ - } & \\
\hline 11 & 28 & & sCCF & 28 & No & - & \multicolumn{2}{|l|}{ - } & \\
\hline 12 & 49 & & $A R$ & 48 & Yes & Sigmoiditis & \multicolumn{2}{|l|}{48} & \\
\hline 13 & 40 & & ADO & 21 & Yes & - & \multicolumn{2}{|l|}{ - } & \\
\hline
\end{tabular}

SCCF spontaneous carotid-cavernous fistula, $F$ female, ICA internal carotid artery, IMT intima-media thickness, $M$ male, NR not reported, $A D O$ arterial dissection and occlusion, $A R$ arterial rupture, AVF arteriovenous fistula

no aneurysm or dissection of the contralateral ICA or in the other cerebral arteries reported on imaging at time of sCCF imaging diagnosis.
A patient (case 7) developed a sCCF during pregnancy, a second patient (case 2) developed a sCCF 2 years after her second pregnancy, a third one (case 10) developed a 
sCCF 3 years after her first pregnancy and a fourth patient (case 1) developed a sCCF 5 years after her second pregnancy. The patient reported as case 12 developed a sCCF 12 years after a second pregnancy. The median age of pregnancy in these 9 patients was 29.0 years, IQR [28.0-30.0], and the median age of occurrence of their fistula was 30.0 years, IQR [25.0-30.0] (P 0.888).

Most patients (76.9\%) were treated by selective occlusion of the fistula (cases 2 to 5 and 7 to 12). Sacrifice of the ICA to achieve occlusion of the SCCF was necessary in 2 (15.4\%) patients (cases 1 and 6), and one (7.7\%) patient (case 13) died before treatment of the sCCF. A contralateral sCCF occurred in a patient (case 7) 5 years after the first sCCF embolization. All patients are still alive, except for case 7 who died of a ruptured aortoiliac dissection 11 years after the first sCCF embolization and 6 years after the contralateral embolization, and case 13 who died of a ruptured splenic dissection 1 month after sCCF diagnosis.

\section{Literature review}

A literature search was performed on July, 2017, using PubMed. Abstracts were reviewed by a single reviewer and full-text articles were obtained for the studies meeting the eligibility criteria. Reference lists were also examined for additional relevant studies not identified through the initial search. Inclusion criteria were English-language and French-language full-text publications published since the 1950s, regarding vEDS patients diagnosed with SCCF.

We identified 51 articles [4-54], mainly case reports, describing 101 direct CCF in 97 vEDS patients (Table 2). There were $77(79.4 \%)$ females and 13 (13.4\%) males. Sex was not reported for 7 (7.2\%) individuals [21, 40]. Median age at direct CCF diagnosis was 31.0 years, IQR [24.0-39.0] (one missing value [34]). Pepin et al. reported an overall mean age of 30.9 years in 27 patients. Five $(5.2 \%)$ patients $[18,40,46,47,50]$ experienced a direct sCCF recurrence on the contralateral ICA 2.5 years, IQR [2.0-3.5] after the first fistula. Of 97 patients, 4 (4.1, 75.0\% male) were diagnosed either with a direct CCF following minor trauma $[7,11,14]$ or with an iatrogenic direct CCF after placement of a Fogarty balloon into the cavernous segment of the ICA [28].

Death was reported for $20(20.6 \%)$ patients $[4,6,7,9-$ $12,19,21,23,24,26,32,43,44,47,49,51]$, of which 14 (70.0\%) died in the course of sCCF management $[4,7,9$, $11,12,19,23,24,32,43,44,49,51]$. COL3A1 variants were reported in 9 patients. There were 5 Glycine missense variants $[5,8,18,51,53]$ and 4 splice-site variants $[8,29,45,51]$. In the other patients, vEDS diagnosis was made either on relevant clinical examination, imaging and medical history $[6,7,9,10,12,15,19,27,28,30,31$, $33,34,39,42,46-50,52]$, histological findings $[6,9,24$, $27,32,43,44,47]$ or on fibroblast culture $[8,15,36,38$, $40,43,44]$. Imaging described marked tortuosity or dysplastic aspect or ectasia of the ICA segment in the neck $[6,10,19,26,39,49]$, sometimes associated with an aneurysm rupture of the intracranial ICA segment into the CS $[8,15,19]$. Aneurysms of the ICA without rupture were also reported [12, 30, 51], sometimes associated with images of dissection [33, 46, 52].

\section{Discussion}

Classification of CCF is based on aetiology (traumatic versus spontaneous), blood flow velocity (high versus low) and anatomy (direct versus dural, or ICA versus ECA). According to the Barrow classification, there are 4 types of CCF [55]. Type A or direct CCF is a high-flow direct shunt due to a posttraumatic or ruptured aneurysm which results in short-circuiting of the ICA arterial blood into the venous system of the CS. Type B, $\mathrm{C}$ and $\mathrm{D}$ are low-flow lesions and grouped under the common definition of dural or indirect CCF. In the general population, direct CCF represents $75 \%$ of all CCF and is mostly posttraumatic $(0.2-0.3 \%$ of craniofacial trauma) [56] or associated with surgical complications, while spontaneous dural (indirect) low-flow CCF are mostly found in postmenopausal hypertensive females [57]. Direct sCCF only accounts for $10 \%$ of all spontaneous CCF [58]. The intracavernous ICA is prone to spontaneous shunting due to the amount and direction of ligaments in relation to the adventitia, the conformation and mobility of the siphon (horizontal segment), and the inextensibility of the dura $[59,60]$. Direct sCCF can be found in patients with intracavernous ICA aneurysms, but only 2 to $9 \%$ of intracavernous ICA aneurysms are complicated with a direct CCF [61]. The rupture of a persistent trigeminal artery-associated aneurysm has also been associated with the development of CCF $[62,63]$. Though direct sCCF seems to be rare in healthy individuals, it appears to be a significant complication in patients with collagenopathies such as vEDS [40, 46, 64]. Spontaneous CCF does not seem to associate with other rare vascular diseases such as Marfan disease or Loeys-Dietz syndrome [65].

Vascular EDS is a rare heritable disease mainly characterized by vascular manifestations such as rupture, dissection or aneurysm affecting large or medium-sized arteries. Cervicocerebral arteries can be affected with disorders such as intracranial aneurysm, carotid artery dissection or direct CCF [64-66]. In our tertiary referral centre, subjects with direct CCF represent $9.8 \%$ of vEDS patients and all fistulas were spontaneous. Posttraumatic direct CCF seems to be rare in vEDS patients and occurs mostly in males $[7,11,14]$.

The median age of our patients at direct SCCF diagnosis, 33.0 years, IQR [26.0-39.5], is quite similar to previous data reported in vEDS population [46, 54,64], and considerably lower than patients free from vEDS who experience CCF [55]. These results are also concordant 
Table 2 Literature review

\begin{tabular}{|c|c|c|c|c|}
\hline Authors & Age (years) & Sex & CCF side and type & COL3A1 variant \\
\hline François P et al. Bull Soc Ophtalmol Fr 1955 [16] & 52 & $\mathrm{~F}$ & Right - NR & NR \\
\hline \multirow[t]{3}{*}{ Graf CJ et al. Arch Neurol 1965 [19] } & 24 & $\mathrm{~F}$ & Left - Direct & NR \\
\hline & 26 & M & Left - Direct & NR \\
\hline & 37 & $\mathrm{~F}$ & Left - Direct & NR \\
\hline Bannerman RM et al. Br Med J 1967 [6] & 37 & $\mathrm{~F}$ & Left - Direct & NR \\
\hline Schoolman A et al. J Neurosurg 1967 [47] & $\begin{array}{l}39 \\
3 \text { weeks later }\end{array}$ & $\mathrm{F}$ & $\begin{array}{l}\text { Left - Direct } \\
\text { Right - Direct }\end{array}$ & NR \\
\hline Julien I et al. Presse Med 1971 [25] & 50 & $\mathrm{~F}$ & Right - Direct & NR \\
\hline Maugery G et al. Bull Soc Ophtalmol Fr 1972 [37] & 17 & $\mathrm{~F}$ & Left - Direct & NR \\
\hline Farley MK et al. Ophthalmology 1983 [12] & 22 & $\mathrm{~F}$ & Left - Direct & NR \\
\hline Guiolet M et al. Bull Soc Ophtalmol 1984 [20] & 31 & $\mathrm{~F}$ & Left - Direct & NR \\
\hline Dany F et al. J Mal Vasc 1986 [9] & 29 & $\mathrm{~F}$ & Right - Direct & NR \\
\hline Lach B et al. J Neurosurg 1987 [32] & 43 & $\mathrm{~F}$ & Left - Direct & $N R$ \\
\hline Peaceman AM et al. Obstet Gynecol 1987 [42] & 27 & $\mathrm{~F}$ & $N R-N R$ & $N R$ \\
\hline Fox R et al. J Neurol Neurosurg Psychiatry 1988 [15] & 20 & M & Left - Direct & $N R$ \\
\hline \multirow[t]{6}{*}{ Halbach W et al. Neurosurgery 1990 [21] } & 22 & $\mathrm{~F}$ & Left - Direct & NR \\
\hline & 19 & $N R$ & NR - Direct & NR \\
\hline & 22 & $\mathrm{~F}$ & Left - Direct & NR \\
\hline & 24 & NR & Right - Direct & NR \\
\hline & 39 & $\mathrm{~F}$ & Left - Direct & NR \\
\hline & 49 & $\mathrm{~F}$ & Right - Direct & NR \\
\hline \multirow[t]{4}{*}{ Pope FM et al. Br J Neurosurg 1991 [44] } & 22 & M & Left - NR & NR \\
\hline & 25 & $\mathrm{~F}$ & Left - NR & NR \\
\hline & 45 & $\mathrm{~F}$ & Right - NR & $N R$ \\
\hline & 27 & $\mathrm{~F}$ & Left - NR & NR \\
\hline Schievink WI et al. J Neurosurg 1991 [46] & $\begin{array}{l}17 \\
20\end{array}$ & $\mathrm{~F}$ & $\begin{array}{l}\text { Left }- \text { Direct } \\
\text { Right - Direct }\end{array}$ & NR \\
\hline Kashiwagi S et al. Surg Neurol 1993 [27] & 22 & M & Left - Direct & NR \\
\hline \multirow[t]{6}{*}{ North NK et al. Ann Neurol 1995 [40] } & 17 & $\mathrm{~F}$ & $N R-N R$ & NR \\
\hline & 27 & NR & $N R-N R$ & $N R$ \\
\hline & 32 & NR & $N R-N R$ & NR \\
\hline & 24 & NR & $N R-N R$ & NR \\
\hline & 28 & NR & $N R-N R$ & NR \\
\hline & $\begin{array}{l}28 \\
33\end{array}$ & NR & $\begin{array}{l}\mathrm{NR}-\mathrm{NR} \\
\text { Contralateral - NR }\end{array}$ & NR \\
\hline Forlodou P et al. Neuroradiology 1996 [14] & 40 & $\mathrm{~F}$ & Right - Traumatic, direct & NR \\
\hline \multirow[t]{3}{*}{ Debrun GM et al. Surg Neurol 1996 [10] } & 39 & $\mathrm{~F}$ & Right - NR & NR \\
\hline & 39 & $\mathrm{~F}$ & Left - NR & NR \\
\hline & 39 & $\mathrm{~F}$ & Left - NR & NR \\
\hline Pollack JS et al. Arch Ophthalmol 1997 [43] & 33 & $\mathrm{~F}$ & Right - Direct & NR \\
\hline Bashir Q et al. Interv Neuroradiol 1999 [7] & 50 & $\mathrm{~F}$ & Left - Traumatic, direct & NR \\
\hline Koh J-H et al. Circulation 1999 [30] & 21 & $\mathrm{~F}$ & Left - Direct & NR \\
\hline \multirow[t]{2}{*}{ Horowitz MB et al. AJNR Am J Neuroradiol 2000 [23] } & 18 & $\mathrm{~F}$ & Left - Direct & $N R$ \\
\hline & 40 & $\mathrm{~F}$ & Right - Direct & NR \\
\hline Kanner AK et al. J Neurosurg 2000 [26] & 33 & $\mathrm{~F}$ & Left - Direct & NR \\
\hline
\end{tabular}


Table 2 Literature review (Continued)

\begin{tabular}{|c|c|c|c|c|}
\hline Authors & Age (years) & Sex & CCF side and type & COL3A1 variant \\
\hline \multirow[t]{2}{*}{ Chuman H et al. J Neuroophthalmol 2002 [8] } & 57 & M & Left - Direct & IVS8+5G >A \\
\hline & 48 & $\mathrm{~F}$ & Left - Direct & C. $544 G>S$ \\
\hline Favrole P et al. La Lettre du Neurologue 2003 [13] & 32 & $\mathrm{~F}$ & Left - Direct & $N R$ \\
\hline Mitsuhashi T et al. Neurol Med Chir (Tokyo) 2004 [38] & 30 & $\mathrm{~F}$ & Right - Direct & NR \\
\hline Desal HA et al. Neuroradiology 2005 [11] & 48 & $\mathrm{~F}$ & Left - Traumatic & $N R$ \\
\hline Jindal R et al. Eur J Vasc Endovasc Surg Extra 2005 [24] & 30 & $\mathrm{~F}$ & Right - Direct (pregnancy) & NR \\
\hline Hollands JK et al. Neuroradiology 2006 [22] & 34 & $\mathrm{~F}$ & Left - Direct & NR \\
\hline Usinskiene J et al. Cardiovasc Intervent Radiol 2006 [49] & 25 & $\mathrm{~F}$ & Right - Direct & NR \\
\hline Van Overmeire O et al. Interv Neuroradiol 2006 [4] & 45 & $\mathrm{~F}$ & Left - Direct & NR \\
\hline \multirow[t]{2}{*}{ Yang JH et al. J Korean Med Sci 2007 [51] } & 48 & $\mathrm{~F}$ & Left - Direct & c. $2195 G>T$ \\
\hline & 36 & $\mathrm{~F}$ & Left - Direct & c.3221_3235dup \\
\hline Zilocchi M et al. AJR Am J Roentgenol 2007 [52] & 20 & $\mathrm{~F}$ & NR - Direct & NR \\
\hline Drera B et al. J Derm Sci 2011 [53] & 32 & $\mathrm{~F}$ & $N R-N R$ & c. $1655 A>G$ \\
\hline Khan A et al. J Neurointervent Surg 2012 [28] & 20 & M & Right - Traumatic, direct & NR \\
\hline Mammen S et al. Neurol India 2012 [35] & 27 & $\mathrm{~F}$ & Right - Direct & $N R$ \\
\hline Gauthier CE et al. J Mal Vasc 2013 [17] & 25 & $\mathrm{~F}$ & NR - Direct & NR \\
\hline Girardin M et al. Ann Dermatol Venereol 2013 [18] & $\begin{array}{l}32 \\
34\end{array}$ & $\mathrm{~F}$ & $\begin{array}{l}\text { Right - Direct } \\
\text { Left - Direct }\end{array}$ & p.(Gly912Asp) \\
\hline Wang Q et al. J Neurol Surg A Cent Eur Neurosurg 2013 [50] & $\begin{array}{l}37 \\
39\end{array}$ & $\mathrm{~F}$ & $\begin{array}{l}\text { Left - Direct } \\
\text { Right - Direct }\end{array}$ & NR \\
\hline Ananth AL et al. Semin Pediatr Neurol 2014 [5] & 17 & $\mathrm{~F}$ & Left - Direct & c.3158G>A \\
\hline Kim JG et al. J Korean Neurosurg Soc 2014 [29] & 46 & $\mathrm{~F}$ & Right - Direct & c. $1662+1 G>A$ \\
\hline Pepin M et al. NEJM 2014 [54] & Mean age 30.9 & $22 \mathrm{~F}, 5 \mathrm{M}$ & $N R-N R$ & NR \\
\hline Tanaka T et al. Neurol Med Chir (Tokyo) 2014 [48] & 37 & $\mathrm{~F}$ & Left - Direct & NR \\
\hline Kojima A et al. Interv Neuroradiol 2015 [31] & 59 & $\mathrm{~F}$ & Right - Direct & NR \\
\hline Linfante I et al. J Neurointervent Surg 2015 [34] & NR & M & Right - Direct & NR \\
\hline Liang JW et al. Neurology 2016 [33] & 25 & $\mathrm{~F}$ & Right - Direct & NR \\
\hline Nakagawa I et al. J Neurolnterv Surg 2016 [39] & 24 & M & Right - Direct & NR \\
\hline Ohlsson M et al. Neuroradiology 2016 [41] & 33 & $\mathrm{~F}$ & Right - Direct & NR \\
\hline Samaraweera APR et al. Neurology 2016 [45] & 40 & $\mathrm{~F}$ & Right - Direct & c. $1347+1 G>A$ \\
\hline Masson-Roy J et al. Can J Neurol Sci 2017 [36] & 39 & $\mathrm{~F}$ & Left - Direct & NR \\
\hline
\end{tabular}

CCF carotid-cavernous fistula, $F$ female, $M$ male, $N R$ not reported

with the median age (31.0 years, IQR [24.0-39.0]) of the patients identified in the literature review. In our series, it is remarkable that 9 patients (69.2\%) experienced a direct $\mathrm{sCCF}$ as their first vascular event, prompting further investigations for vEDS molecular diagnosis in 4 patients only. Notably, direct sCCF has recently been included in the 2017 classification for vEDS as a major diagnosis criterion [2]. As direct $\mathrm{SCCF}$ in young patients seems to be pathognomonic of vEDS, genetic testing of the COL3A1 gene should be mandatory in such patients.

The type of pathogenic variant identified within the COL3A1 gene encoding the pro-alphal chain of type III procollagen in vEDS patients who experienced sCCF is another interesting finding. The natural course of vEDS depends on the type of COL3A1 variant, and there are more severe clinical and phenotypical presentations in Glycine missense and splice-site variants than in variants leading to haploinsufficiency [67]. Our 13 patients presented either with heterozygous Glycine missense or splice-site variants of exons encoding a triple helix sequence. The literature review identified 9 patients with available pathogenic variants within the COL3A1 gene, and all were unsurprisingly either Glycine missense $[5,8,18,51,53]$ or splice-site variants $[8,29,45,51]$. Therefore, it seems reasonable to hypothesize there might be a strong association between these variants and the occurrence of sCCF, while haploinsufficiency does not associate with fistulas. However, the total number of pathogenic variants identified in our patients or reported in the literature $(22 / 97,22.7 \%)$ is 
too small to confirm this genotype-phenotype correlation. As the genetic test is now mandatory to confirm clinical diagnosis, the presence of pathogenic COL3A1 variants should be systematically reported in future articles related to sCCF.

In vEDS patients, spontaneous rupture of a tortuous ICA emerging from the petrous bone into the CS can result in a direct fistula with $[8,15,19]$ or without $[6,10,19,26,39,49]$ a previous known intracranial ICA aneurysm. Another mechanism could be a spontaneous dissection of the ICA with pseudoaneurysm formation [68]. Spontaneous ICA dissection leading to direct $\mathrm{sCCF}$ is described in 5 of our patients (cases 1, 6, 7, 11 and 12) and in the literature review [33, 46, 52]. Intracranial arteries have a histological constitution that reportedly differs from diameter-matched extracranial arteries. They have a decreased amount of elastic fibers in the media and adventitia layers, along with thinner collagen fibers and no external elastic lamina [69]. It is well known that vEDS leads to vascular complications due to structural weakness of the artery wall secondary to type III collagen defects. Therefore, arterial ruptures can also occur on previously non-aneurysmal arteries as we found in 3 patients (cases 5, 9 and 13). Notably, direct sCCF in vEDS patients do not systematically result from aneurysm rupture or dissection of the cavernous ICA and cannot be exclusively described as a complication of an aneurysm or dissection of the cavernous ICA. An explanation for such spontaneous ruptures in seemingly healthy arteries can be found in Boutouyrie et al. [70] who demonstrated an increased carotid circumferential wall stress and a higher carotid distensibility in vEDS patients compared with healthy individuals. Moreover, vEDS patients are known to have lower IMT [70] and lower diastolic-systolic arterial stiffening than healthy control individuals [71]. Impairment of type III collagen generates a lower carotid stiffness and an abnormally low IMT, leading to higher wall stress and risk of arterial rupture. As direct sCCF is probably due to a sudden increase of the ICA intraluminal pressure [72], the previous findings explain why vEDS are at high risk for direct sCCF.

The male to female ratios in our study (0.08) and literature review (0.15) stress the fact that female vEDS patients seem to be more at risk than males for direct sCCF. In comparison, there was a 0.79 male to female ratio in our non-sCCF vEDS patients. In addition to potential sex differences in IMT, sex differences in ICA anatomy could account for a higher prevalence of fistulas in females. Though gathering evidence in vEDS patients is challenging, inferring results from the general population is a first step in understanding the female predominance for sCCF in vEDS. Differences between males and females in various segments of the vascular system have been reported [73-75], as well as in intracranial arterial bifurcations and more specifically of the ICA $[76,77]$, suggesting the involvement of a physiological or an anatomical factor. First of all, sex differences in ICA can be found in the diameter of the parent ICA and its largest and smallest branches, with a significantly larger diameter in male vessels than in female vessels $[77,78]$. Secondly, the study of ICA maximum wall shear stress shows a $50 \%$ higher stress in the female bifurcation compared with the male bifurcation [77]. As females have smaller ICA, their vessel walls are exposed to higher blood flow velocity, and this shear stress is reflected through a higher pressure drop in the female bifurcation compared with the male bifurcation. Vessel morphology and more specifically vessel curvature is also an interesting factor to take into account to determine hemodynamic patterns. Healthy females reportedly have higher mean curvature of their intracranial ICA than males $(P$ 0.04) with a general tendency to a more curved ICA [79]. Only $20.5 \%$ of males have their peak curvature located within the CS, in comparison with as much as $45.1 \%$ of females. Therefore, we hypothesize that anatomical differences account for an irregular blood-flow pattern-which in turn accounts for the alteration of the arterial wall-due to higher shear forces in female intracranial ICA, and lead to more ICA ruptures and fistulas in female vEDS patients. Finally, evidence regarding lower IMT in healthy females compared to males can be found in the literature [80-82]: sex is significantly correlated with carotid artery IMT $(P$ 0.001), as females have significantly lower IMT than age matched males [82]. However, due to the rarity of vEDS, there is no available evidence in the literature regarding IMT differences between male and female vEDS patients. Moreover, as carotid IMT is measured on the extracranial part of the carotid artery $1 \mathrm{~cm}$ beneath the bifurcation, the IMT profile of proximal ICA might not be translatable into structural fragility of the cavernous ICA. Nonetheless, assuming that IMT difference between healthy male and female individuals might also be found in vEDS males and females could account for the overwhelming prevalence of direct sCCF in female vEDS patients.

Another appealing and complementary hypothesis for the frequent occurrence of direct sCCF in vEDS females could be the decrease of wall thickness due to sex hormones, and in particular the role of oestrogens on arterial wall remodelling. An arteriovenous fistula model in rats reveals a significant decrease in wall thickness of the proximal and distal aorta in castrated male rats receiving oestrogens [83]. These results are consistent with the findings of a previous study: neointima formation is reduced by $60 \%$ in rats treated daily by oestrogens before and after balloon injury of carotid artery [84]. The role of oestrogens in spontaneous rupture of carotid-cavernous aneurysm has also been suspected during pregnancy in healthy females free from 
pregnancy-induced hypertension $[85,86]$. We could not find evidence of oestrogen taking in oral-contraceptives for example in our female vEDS patients who experienced direct SCCF, but it is noteworthy that the median age of pregnancy in these patients is quite similar to the median age of occurrence of their sCCF. These results lead us to think that collagen fragility, IMT and anatomy differences are not the only factors predisposing to the rupture of arteries in vEDS females.

\section{Conclusions}

Patients with vEDS have greater risk than healthy individuals to develop direct sCCF due to their fragile vessels walls. Direct sCCF may occur spontaneously by rupture of the ICA, secondary to the rupture of an ICA aneurysm or by dissection of the ICA. The type of variant at the COL3A1 gene associates with the occurrence of fistulas, as only Glycine missense and splice-site variants were identified in our sCCF patients. Female vEDS patients evidently seem more at risk for direct sCCF than males. We hypothesize that this sex difference is essentially linked to ICA anatomical and possible IMT differences between females and males but might also be amplified by hormonal differences. These hypotheses call for further investigations in vEDS patients.

Finally, direct sCCF can be the first symptomatic event in a previously non-diagnosed vEDS individual: in one third of our patients, the occurrence of a fistula led to the molecular diagnosis of vEDS. As SCCF seems to be highly suggestive and possibly pathognomonic of vEDS, type III collagen deficiency should be suspected in young patients and especially in females presenting with a direct SCCF.

\section{Abbreviations}

CCF: Carotid-cavernous fistula; Cl: Confidence interval; CS: Cavernous sinus; ECA: External carotid artery; EDS: Ehlers-Danlos syndrome; ICA: Internal carotid artery; IMT: Intima-media thickness; IQR: Inter quartile range; sCCF: Spontaneous carotid-cavernous fistula; vEDS: Vascular Ehlers-Danlos syndrome

\section{Availability of data and materials}

The datasets used during the current study are available from the corresponding author on reasonable request.

\section{Authors' contributions}

SA carried out study concept and design, acquisition of data, analysis and interpretation of data. DT carried out critical revision of manuscript for intellectual content. JA carried out critical revision of manuscript for intellectual content. VD carried out critical revision of manuscript for intellectual content. AL carried out critical revision of manuscript for intellectual content. XJ carried out critical revision of manuscript for intellectual content. MF carried out study concept and design, and critical revision of manuscript for intellectual content. All authors read and approved the final manuscript.

\section{Ethics approval and consent to participate}

Approval from an ethical standards committee to conduct this study based on medical records was received by the Comité de Protection des Personnes lle-de-France 2 (IRB 00001072).
Consent for publication

Not applicable.

\section{Competing interests}

The authors declare that they have no competing interests.

\section{Publisher's Note}

Springer Nature remains neutral with regard to jurisdictional claims in published maps and institutional affiliations.

\section{Author details}

${ }^{1}$ Hôpital Européen Georges Pompidou, Département de Génétique, Centre de Référence des Maladies Vasculaires Rares, Hôpital Européen Georges Pompidou, AP-HP, 20-40 rue Leblanc, 75908 Paris Cedex 15, France. ${ }^{2}$ Sorbonne Paris Cité, Faculté de Médecine, Université Paris Descartes, Paris, France. ${ }^{3}$ Service d'imagerie morphologique et fonctionnelle, Centre hospitalier Sainte-Anne, Paris, France. ${ }^{4}$ INSERM, U894, IMA-BRAIN, DHU NeuroVasc Sorbonne Paris Cité, Paris, France. ${ }^{5}$ INSERM, U970, Paris centre de Recherche Cardiovasculaire - PARCC, Paris, France.

Received: 21 December 2017 Accepted: 13 June 2018

Published online: 25 June 2018

References

1. Beighton P, De Paepe A, Steinmann B, Tsipouras P, Wenstrup RJ. EhlersDanlos syndromes: revised nosology, Villefranche, 1997. Ehlers-Danlos National Foundation (USA) and Ehlers-Danlos Support Group (UK). Am J Med Genet. 1998;77(1):31-7.

2. Malfait F, Francomano C, Byers P, Belmont J, Berglund B, Black J, Bloom L, Bowen JM, Brady AF, Burrows NP, et al. The 2017 international classification of the Ehlers-Danlos syndromes. Am J Med Genet C Semin Med Genet. 2017;175(1):8-26.

3. Superti-Furga A, Gugler E, Gitzelmann R, Steinmann B. Ehlers-Danlos syndrome type IV: a multi-exon deletion in one of the two COL3A1 alleles affecting structure, stability, and processing of type III procollagen. J Biol Chem. 1988;263(13):6226-32.

4. Van Overmeire O, De Keukeleire K, Van Langenhove P, Defreyne L. Carotidcavernous fistula in ehlers-danlos syndrome by pure transvenous approach. Interv Neuroradiol. 2006;12(1):45-51.

5. Ananth AL, Yang Y, Lalani SR, Lotze TB. An unusual cause of peroneal neuropathy. Semin Pediatr Neurol. 2014;21(2):77-81.

6. Bannerman RM, Graf CJ, Upson JF. Ehlers-Danlos syndrome. Br Med J. 1967; 3(5564):558-9.

7. Bashir Q, Thornton J, Alp S, Debrun GM, Aletich VA, Charbel F, Ausman $J$, Polet H. Carotid-cavernous fistula associated with Ehlers-Danlos syndrome type IV. A case report and review of literature. Interv Neuroradiol. 1999;5(4):313-20.

8. Chuman H, Trobe JD, Petty EM, Schwarze U, Pepin M, Byers PH, Deveikis JP. Spontaneous direct carotid-cavernous fistula in Ehlers-Danlos syndrome type IV: two case reports and a review of the literature. J Neuroophthalmol. 2002;22(2):75-81.

9. Dany F, Fraysse A, Priollet P, Brutus P, Bokor J, Catanzano G, Bernard P, Christides C, Beylot C. Dysmorphic syndrome and vascular dysplasia: an atypical form of type IV Ehlers-Danlos syndrome. J Mal Vasc. 1986;11(3):263-9.

10. Debrun GM, Aletich VA, Miller NR, DeKeiser RJ. Three cases of spontaneous direct carotid cavernous fistulas associated with Ehlers-Danlos syndrome type IV. Surg Neurol. 1996;46(3):247-52.

11. Desal HA, Toulgoat F, Raoul S, Guillon B, Bommard S, Naudou-Giron E, Auffray-Calvier E, de Kersaint-Gilly A. Ehlers-Danlos syndrome type IV and recurrent carotid-cavernous fistula: review of the literature, endovascular approach, technique and difficulties. Neuroradiology. 2005;47(4):300-4.

12. Farley MK, Clark RD, Fallor MK, Geggel HS, Heckenlively JR. Spontaneous carotid-cavernous fistula and the Ehlers-Danlos syndromes. Ophthalmology. 1983:90(11):1337-42.

13. Favrole P, Saint-Maurice JP. Fistule directe carotido-caverneuse spontanée et syndrome d'Ehlers-Danlos de type IV. La Lettre du Neurologue. 2003; VII(4):133.

14. Forlodou P, de Kersaint-Gilly A, Pizzanelli J, Viarouge MP, Auffray-Calvier E. Ehlers-Danlos syndrome with a spontaneous caroticocavernous fistula occluded by detachable balloon: case report and review of literature. Neuroradiology. 1996;38(6):595-7. 
15. Fox R, Pope FM, Narcisi P, Nicholls AC, Kendall BE, Hourihan MD, Compston DA. Spontaneous carotid cavernous fistula in Ehlers Danlos syndrome. J Neurol Neurosurg Psychiatry. 1988;51(7):984-6.

16. Francois $P$, Woillez $M$, Warrot, Maillet $P$. Ehlers-Danlos disease with intracranial arteriovenous aneurysm. Bull Soc Ophtalmol Fr. 1955;5:392-5.

17. Gauthier CE, Onesippe E, Vircoulon M, Boulon C, Constans J. Hemoptysis and Ehlers-Danlos vascular disease. J Mal Vasc. 2013;38(3):218-9.

18. Girardin M, Puzenat E, Humbert P, Aubin F. Bilateral spontaneous carotidcavernous fistula revealing Ehler-Danlos disease. Ann Dermatol Venereol. 2013;140(4):296-9.

19. Graf CJ. Spontaneous carotid-cavernous fistula. Ehlers-Danlos syndrome and related conditions. Arch Neurol. 1965;13(6):662-72.

20. Guiolet M, Jouhaud F, Malbrel C, Augustin P. Ehlers-Danlos diseasearteriovenous fistula. Bull Soc Ophtalmol Fr. 1984;84(3):267-8.

21. Halbach W, Higashida RT, Dowd CF, Barnwell SL, Hieshima GB. Treatment of carotid-cavernous fistulas associated with Ehlers-Danlos syndrome. Neurosurgery. 1990;26(6):1021-7.

22. Hollands JK, Santarius T, Kirkpatrick PJ, Higgins JN. Treatment of a direct carotid-cavernous fistula in a patient with type IV Ehlers-Danlos syndrome: a novel approach. Neuroradiology. 2006;48(7):491-4.

23. Horowitz MB, Purdy PD, Valentine RJ, Morrill K. Remote vascular catastrophes after neurovascular interventional therapy for type 4 EhlersDanlos syndrome. AJNR Am J Neuroradiol. 2000;21(5):974-6.

24. Jindal R, Choong A, Arul D, Dhanjil S, Chataway J, Cheshire NJW. Vascular manifestations of type IV Ehlers-Danlos syndrome. Eur J Vasc Endovasc Surg. 2005;9:135-8

25. Julien I, De Boucaud D. Spontaneous carotido-cavernous fistula and EhlersDanlos diseases. Presse Med. 1971;79(27):1241-2.

26. Kanner AA, Maimon S, Rappaport ZH. Treatment of spontaneous carotidcavernous fistula in Ehlers-Danlos syndrome by transvenous occlusion with Guglielmi detachable coils. Case report and review of the literature. J Neurosurg. 2000:93(4):689-92

27. Kashiwagi S, Tsuchida E, Goto K, Shiroyama Y, Yamashita T, Takahasi M, Ito H. Balloon occlusion of a spontaneous carotid-cavernous fistula in EhlersDanlos syndrome type IV. Surg Neurol. 1993;39(3):187-90.

28. Khan A, Chaudhary N, Pandey AS, Gemmete JJ. Direct puncture of the highest cervical segment of the internal carotid artery for treatment of an iatrogenic carotid cavernous fistula in a patient with Ehlers-Danlos syndrome. J Neurointerv Surg. 2012;4(5):e29.

29. Kim JG, Cho WS, Kang HS, Kim JE. Spontaneous carotid-cavernous fistula in the type IV Ehlers-Danlos syndrome. J Korean Neurosurg Soc. 2014;55(2):92-5.

30. Koh JH, Kim JS, Hong SC, Choe YH, Do YS, Byun HS, Lee WR, Kim DK. Skin manifestations, multiple aneurysms, and carotid-cavernous fistula in EhlersDanlos syndrome type IV. Circulation. 1999;100(13):e57-8.

31. Kojima A, Saga I, Tomio R, Kosho T, Hatamochi A. Aggressive change of a carotid-cavernous fistula in a patient with Ehlers-Danlos syndrome type IV. Interv Neuroradiol. 2015:21(3):341-5.

32. Lach B, Nair SG, Russell NA, Benoit BG. Spontaneous carotid-cavernous fistula and multiple arterial dissections in type IV Ehlers-Danlos syndrome. Case report. J Neurosurg. 1987;66(3):462-7.

33. Liang JW, Horowitz D. Teaching Neurolmages: carotid cavernous fistula in a patient with Ehlers-Danlos syndrome. Neurology. 2016;87(9):e99.

34. Linfante I, Lin E, Knott E, Katzen B, Dabus G. Endovascular repair of direct carotidcavernous fistula in Ehlers-Danlos type IV. J Neurointerv Surg. 2015;7(1):e3.

35. Mammen S, Keshava SN, Danda S, Raju R, Chacko AG. Endovascular management of carotid-cavernous fistula in Ehlers-Danlos syndrome type IV. Neurol India. 2012;60(1):119-21.

36. Masson-Roy J, Savard M, Mackey A. Carotid cavernous fistula in a patient with type IV Ehlers-Danlos syndrome. Can J Neurol Sci. 2017:44(4):427-8.

37. Maugery G, Rambaud G, Franck JP, Villon JC. Spontaneous caroticocavernous fistula in a young patient in a multiple abnormality context. Bull Soc Ophtalmol Fr. 1972;12(4):499-502.

38. Mitsuhashi T, Miyajima M, Saitoh R, Nakao Y, Hishii M, Arai H. Spontaneous carotid-cavernous fistula in a patient with Ehlers-Danlos syndrome type IVcase report. Neurol Med Chir (Tokyo). 2004;44(10):548-53.

39. Nakagawa I, Park HS, Wada T, Takayama K, Nakagawa H, Kichikawa K, Nakase H. A novel approach to the treatment of a direct carotid-cavernous fistula in a patient with Ehlers-Danlos syndrome type IV. J Neurointerv Surg. 2016;8(1):e2.

40. North KN, Whiteman DA, Pepin MG, Byers PH. Cerebrovascular complications in Ehlers-Danlos syndrome type IV. Ann Neurol. 1995; 38(6):960-4
41. Ohlsson M, Consoli A, Rodesch G. Endovascular treatment of caroticocavernous fistulas with acrylic glue: a series of nine cases. Neuroradiology. 2016;58(12):1181-8.

42. Peaceman AM, Cruikshank DP. Ehlers-Danlos syndrome and pregnancy: association of type IV disease with maternal death. Obstet Gynecol. 1987; 69(3 Pt 2):428-31.

43. Pollack JS, Custer PL, Hart WM, Smith ME, Fitzpatrick MM. Ocular complications in Ehlers-Danlos syndrome type IV. Arch Ophthalmol. 1997; 115(3):416-9.

44. Pope FM, Kendall BE, Slapak Gl, Kapoor R, McDonald WI, Compston DA, Mitchell R, Hope DT, Millar-Craig MW, Dean JC, et al. Type III collagen mutations cause fragile cerebral arteries. Br J Neurosurg. 1991;5(6):551-74.

45. Samaraweera AP, Laverse E, Henderson A. Pearls \& Oy-sters: vascular EDS presenting with acute proptosis: always revisit the history. Neurology. 2016; 87(4):e36-8

46. Schievink WI, Piepgras DG, Earnest F 4th, Gordon H. Spontaneous carotidcavernous fistulae in Ehlers-Danlos syndrome type IV. Case report. Neurosurg. 1991;74(6):991-8.

47. Schoolman A, Kepes JJ. Bilateral spontaneous carotid-cavernous fistulae in Ehlers-Danlos syndrome. Case report. J Neurosurg. 1967;26(1):82-6.

48. Tanaka T, Hayakawa M, Sadato A, Adachi K, Watabe T, Maeda S, Ohmura M, Hirose Y. Transvenous embolization for carotid-cavernous fistula in a patient with vascular type of Ehlers-Danlos syndrome-direct superior ophthalmic vein approach: case report. Neurol Med Chir (Tokyo). 2014;54(2):155-60.

49. Usinskiene J, Mazighi M, Bisdorff A, Houdart E. Fatal peritoneal bleeding following embolization of a carotid-cavernous fistula in Ehlers-Danlos syndrome type IV. Cardiovasc Intervent Radiol. 2006;29(6):1104-6.

50. Wang Q, Chen G. Endovascular treatment of bilateral multiple carotidcavernous fistulas in a patient with Ehlers-Danlos syndrome. J Neurol Surg A Cent Eur Neurosurg. 2013;74(Suppl 1):e41-4.

51. Yang JH, Lee ST, Kim JA, Kim SH, Jang SY, Ki CS, Kim DK. Genetic analysis of three Korean patients with clinical features of Ehlers-Danlos syndrome type IV. J Korean Med Sci. 2007;22(4):698-705.

52. Zilocchi M, Macedo TA, Oderich GS, Vrtiska TJ, Biondetti PR, Stanson AW. Vascular Ehlers-Danlos syndrome: imaging findings. AJR Am J Roentgenol. 2007:189(3):712-9.

53. Drera B, Zoppi N, Ritelli M, Tadini G, Venturini M, Wischmeijer A, Nicolazzi MA, Musumeci A, Penco S, Buscemi L, et al. Diagnosis of vascular EhlersDanlos syndrome in Italy: clinical findings and novel COL3A1 mutations. J Dermatol Sci. 2011;64(3):237-40.

54. Pepin MG, Schwarze U, Rice KM, Liu M, Leistritz D, Byers PH. Survival is affected by mutation type and molecular mechanism in vascular EhlersDanlos syndrome (EDS type IV). Genet Med. 2014;16(12):881-8.

55. Barrow DL, Spector RH, Braun IF, Landman JA, Tindall SC, Tindall GT. Classification and treatment of spontaneous carotid-cavernous sinus fistulas. J Neurosurg. 1985;62(2):248-56

56. Lewis Al, Tomsick TA, Tew JM Jr. Management of 100 consecutive direct carotid-cavernous fistulas: results of treatment with detachable balloons. Neurosurgery. 1995:36(2):239-44. discussion 244-235

57. Miller NR. Dural carotid-cavernous fistulas: epidemiology, clinical presentation, and management. Neurosurg Clin N Am. 2012;23(1):179-92.

58. Vinuela F, Fox AJ, Debrun GM, Peerless SJ, Drake CG. Spontaneous carotidcavernous fistulas: clinical, radiological, and therapeutic considerations. Experience with 20 cases. J Neurosurg. 1984;60(5):976-84.

59. Harris FS, Rhoton AL. Anatomy of the cavernous sinus. A microsurgical study. J Neurosurg. 1976;45(2):169-80.

60. Lee JH, Lee HK, Park JK, Choi CG, Suh DC. Cavernous sinus syndrome: clinical features and differential diagnosis with MR imaging. AJR Am J Roentgenol. 2003;181(2):583-90.

61. Kobayashi N, Miyachi S, Negoro M, Suzuki O, Hattori K, Kojima T, Yoshida J. Endovascular treatment strategy for direct carotid-cavernous fistulas resulting from rupture of intracavernous carotid aneurysms. AJNR Am J Neuroradiol. 2003;24(9):1789-96.

62. Berger MS, Hosobuchi Y. Cavernous sinus fistula caused by intracavernous rupture of a persistent primitive trigeminal artery. Case report. J Neurosurg. 1984;61(2):391-5.

63. Menshawi K, Mohr JP, Gutierrez J. A functional perspective on the embryology and anatomy of the cerebral blood supply. J Stroke. 2015;17(2):144-58.

64. Pepin M, Schwarze U, Superti-Furga A, Byers PH. Clinical and genetic features of Ehlers-Danlos syndrome type IV, the vascular type. N Engl J Med. 2000;342(10):673-80 
65. Debette S, Germain DP. Neurologic manifestations of inherited disorders of connective tissue. Handb Clin Neurol. 2014;119:565-76.

66. Schievink WI, Limburg M, Oorthuys JW, Fleury P, Pope FM. Cerebrovascular disease in Ehlers-Danlos syndrome type IV. Stroke. 1990;21(4):626-32.

67. Frank M, Albuisson J, Ranque B, Golmard L, Mazzella JM, Bal-Theoleyre L, Fauret AL, Mirault T, Denarie N, Mousseaux E, et al. The type of variants at the COL3A1 gene associates with the phenotype and severity of vascular Ehlers-Danlos syndrome. Eur J Hum Genet. 2015;23(12):1657-64.

68. Germain DP, Herrera-Guzman Y. Vascular Ehlers-Danlos syndrome. Ann Genet. 2004:47(1):1-9.

69. Kitanaka C, Sasaki T, Equchi T, Teraoka A, Nakane M, Hoya K. Intracranial vertebral artery dissections: clinical, radiological features, and surgical considerations. Neurosurgery. 1994;34(4):620-6. discussion 626-627

70. Boutouyrie P, Germain DP, Fiessinger JN, Laloux B, Perdu J, Laurent S. Increased carotid wall stress in vascular Ehlers-Danlos syndrome. Circulation. 2004;109(12):1530-5.

71. Mirault T, Pernot M, Frank M, Couade M, Niarra R, Azizi M, Emmerich J, Jeunemaitre X, Fink M, Tanter M, et al. Carotid stiffness change over the cardiac cycle by ultrafast ultrasound imaging in healthy volunteers and vascular EhlersDanlos syndrome. J Hypertens. 2015;33(9):1890-6. discussion 1896

72. Helmke K, Kruger O, Laas R. The direct carotid cavernous fistula: a clinical, pathoanatomical, and physical study. Acta Neurochir. 1994;127(1-2):1-5.

73. Johnsen SH, Joakimsen O, Singh K, Stensland E, Forsdahl SH, Jacobsen BK. Relation of common carotid artery lumen diameter to general arterial dilating diathesis and abdominal aortic aneurysms: the Tromso study. Am J Epidemiol. 2009:169(3):330-8.

74. Muller HR, Brunholzl C, Radu EW, Buser M. Sex and side differences of cerebral arterial caliber. Neuroradiology. 1991;33(3):212-6.

75. Wellman GC, Bonev AD, Nelson MT, Brayden JE. Gender differences in coronary artery diameter involve estrogen, nitric oxide, and $\mathrm{Ca}(2$ +)-dependent K+ channels. Circ Res. 1996;79(5):1024-30.

76. Horiuchi T, Tanaka Y, Hongo K. Sex-related differences in patients treated surgically for aneurysmal subarachnoid hemorrhage. Neurol Med Chir (Tokyo). 2006;46(7):328-32. discussion 332

77. Lindekleiv HM, Valen-Sendstad K, Morgan MK, Mardal KA, Faulder K, Magnus $\mathrm{JH}$, Waterloo K, Romner B, Ingebrigtsen T. Sex differences in intracranial arterial bifurcations. Gend Med. 2010;7(2):149-55.

78. Krejza J, Arkuszewski M, Kasner SE, Weigele J, Ustymowicz A, Hurst RW, Cucchiara BL, Messe SR. Carotid artery diameter in men and women and the relation to body and neck size. Stroke. 2006;37(4):1103-5.

79. Lauric A, Safain MG, Hippelheuser J, Malek AM. High curvature of the internal carotid artery is associated with the presence of intracranial aneurysms. J Neurointerv Surg. 2014;6(10):733-9.

80. Jarauta E, Mateo-Gallego R, Bea A, Burillo E, Calmarza P, Civeira F. Carotid intima-media thickness in subjects with no cardiovascular risk factors. Rev Esp Cardiol. 2010;63(1):97-102.

81. Paul J, Shaw K, Dasgupta S, Ghosh MK. Measurement of intima media thickness of carotid artery by B-mode ultrasound in healthy people of India and Bangladesh, and relation of age and sex with carotid artery intima media thickness: an observational study. J Cardiovasc Dis Res. 2012;3(2):128-31.

82. Su TC, Chien KL, Jeng JS, Chen MF, Hsu HC, Torng PL, Sung FC, Lee YT. Age- and gender-associated determinants of carotid intima-media thickness: a communitybased study. J Atheroscler Thromb. 2012;19(9):872-80.

83. Dorsett-Martin WA, Hester RL. Sex hormones and aortic wall remodeling in an arteriovenous fistula. Gend Med. 2007:4(2):157-69.

84. Mori T, Durand J, Chen Y, Thompson JA, Bakir S, Oparil S. Effects of shortterm estrogen treatment on the neointimal response to balloon injury of rat carotid artery. Am J Cardiol. 2000;85(10):1276-9.

85. Dogan S, Salman MC, Deren O, Geyik S. Carotid-cavernous fistula in term pregnancy due to spontaneous rupture of carotid-cavernous aneurysm. J Obstet Gynaecol Res. 2012;38(2):427-30.

86. Hirata $Y$, Matsukado $Y$, Takeshima H, Seto H. Postpartum regression of a spontaneous carotid-cavernous fistula-case report. Neurol Med Chir (Tokyo). 1988;28(7):673-6.

\section{Ready to submit your research? Choose BMC and benefit from:}

- fast, convenient online submission

- thorough peer review by experienced researchers in your field

- rapid publication on acceptance

- support for research data, including large and complex data types

- gold Open Access which fosters wider collaboration and increased citations

- maximum visibility for your research: over $100 \mathrm{M}$ website views per year

At BMC, research is always in progress.

Learn more biomedcentral.com/submissions 